\section{Indonesian Intangible Cultural Heritage: Uniting Millennial Vernacular Literature and Global Awareness}

\author{
Widyarini Susilo Putri \\ Universitas Merdeka Malang \\ e-mail: widyarini@unmer.ac.id
}

\begin{abstract}
The millennial generation is said as a threat as well as an opportunity to preserve the intangible cultural heritage such as vernacular literature as national identity literature. To unravel this problem, this paper use Theory of Generational Difference. This theory is used to understand the existence of millennial generations more fully and comprehensively. Because they are assets, not threats. Preserving the Vernacular Literature as Indonesian intangible Cultural Heritage is not properly enough to corner the millennial generation with a series of sentences polished with theory and study. Tactical steps are needed to address this phenomenon. Therefore, this research was conducted in several stages, namely; first, outlining vernacular literature as intangible cultural heritage should be preserved. Second, describing and analyzing the existence of the millennial generation as prospective Indonesian literary relay holders using the theory of generational difference. The result then leads to a step of transformation to preserve vernacular literature by increasing global awareness in the praxis form.
\end{abstract}

\section{Keywords}

Intangible Cultural Heritage, Vernacular Literature, Millennial

\section{Introduction}

Vernacular means the language used by a group of people in a particular place. This understanding of medieval European history means something that does not use Latin language/writing. Therefore, the vernacular is interpreted as the opposite of lingual Franca because, at that time, the daily language was Latin. According to Kushartanti, the vernacular language is a variety of languages commonly used in everyday conversation or as a symbol of solidarity. It could also be said that the vernacular is not an official language in a particular context. Regional languages commonly used in everyday conversation, (Kushartanti, 2005) While in Merriam-Webster's Online, vernacular means using a language or dialect native to a region or country rather than a literary, cultured, or foreign language of a group of people living in a particular place. In the context of literary works, vernacular literature means literature using local languages in linguistic contexts. 
This is usually found in local literary works such as folklore or oral literature, myth, and narrative text legend written by an anonymous author. However, it is actually part of the intangible Indonesian cultural heritage.

Since Indonesia became a State Party to the 2003 Convention on the protection of intangible cultural heritage, according to articles 11 and 12 of the 2003 convention, Indonesia is required to regulate the identification and inventory of Indonesian intangible cultural heritage in the territory of the Republic of Indonesia in more inventory updated regularly. In this case, the directorate general of culture through the Directorate of inheritance and cultural diplomacy conducts the recording, stipulation, and determination of intangible cultural heritage. The recording is conducted by 11 (eleven) Centers for Preservation of Cultural Values existed throughout Indonesia. To this recent, 7,241 of 34 provinces have recorded the cultural works. Ministry of Education and Culture in (gln.kemdikbud.go.id, n. d.) its reviews, intangible cultural heritage is intangible/ abstract, such as concepts and technology; and its nature can pass and disappear as time goes by, such as language, music, dance, ceremony, and various other structured behaviors.

Intangible Cultural Heritage based on UNESCO Convention For The Safeguarding Of The Intangible Cultural Heritage 2003 stated that Intangible Cultural Heritage is a variety of practices, representations, expressions, knowledge, skills and instruments, objects, artifacts and cultural spaces associated with it, that the society, groups, and individuals in some cases are part of a cultural heritage. This intangible cultural heritage is passed on from generation to generation, which is continually recreated by communities and groups in response to the surrounding environment, their interaction with their nature and history, and provide a sense of sustainable identity, to respect human culture and creativity.

1. Intangible Cultural Heritage is in the form of, among others, including:

2. Tradition and Oral Expression, including language as a vehicle for intangible cultural heritage.

3. Performing art

4. Customary customs, rites, and celebrations;

5. Knowledge and behavioral habits regarding the universe;

6. Traditional skills.

7. Traditions and Oral Expressions such as language, ancient texts, traditional games, rhymes, folklore, mantras, prayers, folk songs, and others.

8. Performing arts such as dance, sound art, music, theater, film, and others.

9. Customary customs, rites, and celebrations e.g. traditional ceremonies (life cycle ceremonies), social organization systems, traditional economic system, and others.

10. Knowledge and behavioral habits regarding the universe such as traditional knowledge, local wisdom, traditional medical treatment, and others

11. Traditional skills such as traditional technology, traditional architecture, traditional clothing, traditional accessories, traditional crafts, traditional culinary, traditional transportation media, traditional weapons and others (http://gln.kemdikbud.go.id/)

In this case, of course, literature, which has elements of vernacular language, has a very large portion to occupy a position as Indonesian intangible cultural heritage. In the V Indonesian Congress (1988), for example, very optimistically Hutomo stated as cited in Suwondo (2008),

However, we must be aware that Indonesian literature is a "unifying literature" of the Indonesian people because Indonesian literature serves as a marker of "national solidarity", while regional literature serves as a marker of

"identity national"; therefore, they do not need to be contested because everything belongs to us, belonging to the Indonesian nation. (p. 11)

Keith Foulcher also stated in Southeast Asian Journal of Social Science with the title Politics and Literature in Independent Indonesia: The View from the Left uttered that literature as one of parts of evolution of Indonesian national art forms that have significant part in Indonesian national immense history of nationality, thus it means that Literature needed to be preserved well since it is one of Indonesian identity. In the Heritage Book: Management, Interpretation, Identity, Peter Howard define that heritage is as everything that people want to save, including material of culture and nature. During this time, cultural heritage is more aimed at public cultural heritage, such as various objects stored in the museum. According to Howard, everyone also has a life background that can be a separate legacy. Howard believes that everything wanted to be saved because it is considered as part of the nation's character is a part of heritage also.

Howard statement further strengthens the position of vernacular literature as intangible heritage. Referring to Indonesian Heritage Conservation Charter declared in Ciloto on December 13, 2003, heritage is agreed upon as an inheritance. Indonesian heritage includes Natural Heritage, Cultural Heritage, and 
Saujana Heritage. Heritage is a special natural form. Cultural Heritage is the result of the creation, sense, intention and special work of more than 500 ethnic groups in the homeland of Indonesia, individually, as a unity of the Indonesian nation, and in its interaction with other cultures throughout its history.

Cultural Heritage includes tangible and intangible heirlooms. Saujana Heritage is a combination of Natural Heritage and Cultural Heritage in the unity of space and time. Saujana's heirloom is known as a new understanding of the cultural landscape, which focuses on the relationship between culture and nature and is a complex phenomenon with tangible and intangible identities. Adhering to the said explanation, folklore, dance, culinary, traditional music, local literature and others classified to cultural wealth are called heritage. Furthermore, Howard stated that the legacy or heritage of people per person was recognized as the heritage. It depends on their families to keep and maintain memories such as about their grandparents, either in the form of advice, diary, book collection, work ethic, old car, photo album, etc.

The problem is, is it properly enough to preserve Indonesia Intangible Cultural Heritage in order to be approved by UNESCO? Otherwise, its existence is actually being increasingly abandoned by its regenerators in the name of a millennial generation? In this case, it is important then to conduct a study to keep the existence of Indonesian intangible cultural heritage, not only be approved by UNESCO but also be understood by its regenerators as their belief, self-foundation, and philosophy of life to communicate and express their thought. This then underlies why this research is considered important to conduct.

\section{Theoretical Framework}

\subsection{Theory of Generational Differences}

The study use theory of generational difference in aim to make vernacular literature, as vernacular language is a part of, is closer to the next generation. In this case, the first step should be conducted is to identify more closely the vernacular literary re-generation as represented by the Millennial generation.

Manheim (1952) defined a generation as a social construction in which there are groups of people who share the same age and historical experience. In more detail, he explained that individuals as a part of a generation are those who have the same year of birth in a range of 20 years and are in the same social dimension and historical dimension. A definition is specifically developed by Ryder (1965) stated that generation is the aggregate of a group of individuals experiencing the same events in the same time period. In the last few years, the definitions related to generation have experienced significant development. One of them is a definition expressed by Kupperschmidt's (2000), he explained that generation is a group of individuals who identify their group based on the similarity of the year of birth, age, location, and events in the life of the group of individuals who have a significant influence in their growth phase. From those definitions, it cannot be accepted to judge others because of inter-generation matter. It is because each generation certainly has a different perspective. It is not wise for the previous generation to impose their mindsets on younger generations, such as the millennial generation. The theory of generational differences was also popularized by Neil Howe and William Strauss in 1991.

Howe and Strauss $(1991,2000)$, divided generation based on the similarity of the birth time range and the similarity of historical events. The basic understanding of the generation classification is the premise that a generation is a group of individuals influenced by historical events and cultural phenomena occurring and experiencing in their phases of life (Nobel \& Schewe, 2003; Twenge, 2000), and these events and phenomena cause the formation of collective memories that have an impact on their lives (Dencker et al. 2008). Therefore, historical, social, and cultural effects together with these other factors will influence the formation of individual behavior, values, and personality (Caspi \& Roberts, 2001; Caspi et. Al., 2005). From these explanations, there are two main things that underlie the generation classification, namely demographic factors, especially the similarity of birth years, and the second is sociological factors, particularly historical events. According to Parry \& Urwin (2011), the second factor is more widely used as a basis for research on generational differences.

Every generation must have its own character in processing information. The characteristics of each generation emerge from the time when they grew and developed to achieve a collective identity formed from the issues that developed during the period. The generation born above 1983 was a birth group which in 2000 reached the age of fewer than 17 years old (Strauss and Howe, 2000), a late adolescence where the final phase of identity formation occurred before the age of 18 , age is expected to have a commitment to social life of his community in Indonesia. 
This birth group has a variety of terminology. Strauss-Howe called it as "Millennial Generation", while Don Tapscott called it as "Net Generation". Graham Brown in his research called the generation as "Mobile Generation". Because the term "millennial generation" is the most common term, and also more in line with the context of research, the study uses the term millennial generation to describe the generation was born in the information age where media technology developed and integrated with everyday life.

According to Absher and Amidjaya (2008), the millennial generation is the generation born from 1982 to 2002. Generations in this millennial era are also known as Google Generation, Net Generation, Generation Z, Echo Boomers, and Dumbest Generation. The millennial generation can be characterized by the increasing use of communication tools, media and information technology used. Tapscott (2008: 15) stated that the term for the millennial generation is called Z Generation. Some of the characteristics of this generation of Z, such as people who want freedom in choosing their freedom of expression, very happy to do customization and personalization. Therefore, the presence of $Z$ generation will obviously become a new supervisor, a commentator and a trigger of a library change.

Millennial Generation relies heavily on the speed instantly, thus, real-time is the main requirement to connect with this millennial generation. The ease of information can be obtained using the internet. Millennial Generations are innovators because they do more in research, study and work in an innovative environment relying heavily on technology to make changes in various aspects of their lives.

The characteristics related to Millennial generation are clearly all related to technology, for example:

1. Instant Communications this generation lives in a real-time environment and is looking for a convenient way to communicate. Thus, instant communication is an important keyword and is the convenience to do what they like;

2. Network Development, to develop a network allowing the generation to connect and collaborate with each other. Thus, collaboration is a new oxygen in designing their freedom;

3. Gadget-Powered Connection, gadget lovers who always provide connections through gadgets (such as mobile phones, platform games, laptops/ netbooks, etc.). Thus, the use of technology becomes very hyper for this millennial generation.

\section{$3 \quad$ Results and Discussions}

\subsection{Vernacular Literature}

Vernacular literature is referred to a series of Indonesian literary works required using vernacular language as a part of it whereas in this case, it is more specific to vernacular language based on MerriamWebster's Online definition, which defines that vernacular means native language of a group of people who live in a particular place. In the context of literary works, vernacular literature means literature uses local languages while in linguistic contexts, it is usually found in many local literary works, such as folklore or oral literature made by an anonymous author. However, it is actually an integral part of Indonesian cultural heritage as the wealth and identity of the Indonesian people.

The best news is that some of the literary works written in mother tongue and developing as suburb literary works, and oral literature are now being recognized by UNESCO. One of them is the Story of Panji, where the existence of this literary work is not only attached to the identity of national literature but also is developed as a work of oral literature among the Javanese community. A Legend of Panic are reflected the local becoming a spirit of life for the Javanese community. The Story of Panji is an oral literary work from East Java; it is predicted to have emerged since the golden era of Kadiri (Daha). It was very popular in the Majapahit era, so it grew and developed throughout the archipelago, even to the regions of Malay, Thailand, Laos, Myanmar, and Cambodia. In practice, the Panji Story is found in Wayang Beber (Pacitan), Wayang Topeng (Malang), Wayang Thengul (Bojonegoro), Wayang Klithik (Kediri), Penthul Tembem (Madiun), Kethek Ogleng (Madiun), Balinese performing arts, dance Cirebon Mask, and several other folk arts.

Some folklore such as Keong Mas, Ande-ande Lumut, and Golek Kencana are also derivatives of this story. Because there are many stories that are different but interconnected, the stories in various versions are included in a category called "Panji Circumstance". The Panji story itself has many versions. Among the well-known versions, there is so-called Malay literature as Hikayat Cekel Weneng Pati, Hikayat Andakenh Penurat, and so on. The initial text of this romance was written in Middle Javanese. From the Javanese version of the Madya Stage of Javanese, the novel is then adapted into New Javanese, Sudanese, Balinese, 
and Maduranese. In the 16th century, there were also various kinds of adaptations or Malay translations. From this Malay text, the story of Panji then sprout and became known on the Malay Peninsula, Thailand, Cambodia, Myanmar and Vietnam (quoted from Vladimir Braginsky, The Heritage of Traditional Malay Literature; A Historical Survey of Genres, Writing and Literary View. Leiden: KITLV Press, 2004, and RMNg Purbatjaraka. Tjerita Panji in Comparison. Jakarta; Gunung Agung, 1968)

In 2016, finally, the Panji Story was established by the United Nations Educational, Scientific and Cultural Organization (UNESCO) as "World Memory" or Memory of the World (MoW). This is stated in the official website of the Memory of the World - UNESCO dated 31 October 2017. This stipulation indirectly adds to the number of MoWs that Indonesia has obtained namely the Archives of the Dutch East India Company-VOC (2003), Manuscript I La Galigo (2011), Manuscripts of Babad Diponegoro (2013), Negara Krtagama (2013) and Archives of the Asian-African Conference (2015).

Along with the establishment of the Panji Story as the MoW, in fact, in 2017 UNESCO also had established the Borobudur Conservation Archives, and the Indian Ocean Tsunami Archives. However, the study will focus more on Panji Story which is actually not only in the form of ancient text but has developed as oral literature whose existence is loaded with elements of vernacular language. The establishment of a Panji Story by the United Nations Educational, Scientific and Cultural Organization (UNESCO) as "World Memory" or Memory of the World (MoW), indeed, it is a very good achievement for Indonesia, but on the other hand, it leaves a very sad fact. The reason is that the story of Panji, which was established as the Memory of the World (MoW) by UNERSCO, seems to have been largely unknown to Indonesia's regeneration.

Certainly, in the name of the millennial generation, they do not know what Story of Panji is. Do not take the contents of the local wisdom contained in the work, nor do they know it. This is certainly, an irony for the existence of Indonesian literature contained with the contents of Vernacular language, in the context of vernacular language definition as a native language. The most basic question in this matter is that who should be blamed, and what is wrong with this nation, or which is more properly with the millennial era?

\subsection{Vernacular Literature Vs Millenial Generation}

The fact that the more millennial generation does not have any interest in literature fully of vernacular language, the more heartbreaking fact for this nation. When some people keep struggling to make literature in the form of local literature to be recognized by the world, otherwise, there are certain parties as candidates of Indonesian literary relay holders just flocking to leave it. The simplest characteristic showing the more ignored millennial generation with a series of literature created from vernacular languages is in communicating. They are more dominantly using a variety of contemporary slang words which tends to be sarcastic rather than poetic. They have removed the language from its roots. This kind of fact is really disappointing because the existence of the millennial generation is nothing but a portrait of the future of Indonesia literature.

Based on population census data in 2010, the number of millennial generations reached more than 84 million people. Surely, this figure will continue to increase considering the hegemony of technological progress increasingly reaching even to a remote area. This is certainly a new challenge to face the future of vernacular literature. The phenomenon of the poetry interpretation without the approach of literature, ethics, and humanism, also proves the recent generation that is blind to literature.

Certainly, this cannot be ignored because of a big threat to the future of Indonesian literature. An indication of the great nation is it's literary and culture. How does Indonesia have a large population without having sufficient emotional intelligence and humble character? In the philosophy trilogy, humans do not have enough logical values (right-wrong), ethics (good-bad), but also have aesthetics (beautifulunsightly). One form of ethical intelligence is to understand literature. Understanding literature will drive them to become a cultured generation. It is because they can absorb a series of poetic, polite, and ethical words in communication and expression. This is the main characteristic of Indonesia. If the characteristics are left behind, then at the same time, people let the future of literature to run without a commander. Where the future canoe is none other than the young regeneration of Indonesia, which they currently love in the name of themselves as a millennial generation.

Based on Mohamad Burhanuddin's statement (2016), he stated that millennial generation is a generation that is familiar with the technology. They have an ideal view of the world and want to be active in making changes in the world. They often even assume that the world revolves with them as its axis, so they are often regarded as selfish, rebellious and stubborn individuals.

They are in an age of phantasmagoria (phantasm: a product of fantasy or illusion, agrorie: gathering), an age (which according to Yasraf A. Piliang, in the Burhanuddin column) is full of bombardments of images and illusions that come and go at high speed to the space of consciousness because of the easy access to 
various information gates of various media, especially television and internet. That phase is the exact opposite of the earlier era. In which John H. McGlynn in Silenced Voices, Muted Expressions: Indonesian Literature Today in Manoa stated that even literature is muted back then, much censorship from not only Government authorities but also from some various communities. This point shows that the elders and the Millennial are clearly having a huge gap in getting reading materials.

In the article "The Me Generation - Why They Will Save Us All", written by socialist Joel Stein, which was published in the May 2013 edition of TIME Magazine. Stein reviewed a lot of facts that explain why young people born between 1980 and 2000 can be a problem as well as "new dynamics" for the development of the world? This type of generation is referred to as the millennial generation with a dominant character: lazy, narcissistic and proud, and tends to be independent.

Stein underlined the conclusion that they are preventative of all kinds of self-love, neglecting significant information and indulging in irrelevant things on the internet. This generation will be a new marker in the history of civilization. "Millennials are not trying to take over the improvement and development of life, they are growing themselves without the development," Stein wrote. Stein's view of the Millennial Generation seems also quite relevant when faced with facts in the field related to the existence of Millennial Generations in Indonesia. Nevertheless, the problem is whether it is a reflection of their true existence, or is a portrait of the impact of increasingly uncontrolled technological developments. Where information is increasingly booming, then "right and wrong" are increasingly difficult to distinguish.

Of all the premises above, it can be understood that the existence of the Millennial Generation can be assumed as a threat to the future of vernacular literature if it is not immediately addressed with anticipatory steps in guarding vernacular literature. It is because of the position of vernacular literature in the era of the millennial generation can be said to be at the nadir. Let alone literature containing vernacular elements and national literature in general, they still don't know much about them. The question is, are they truly worthy of being positioned as the party to blame?

Most of the reviews about the existence of the Millennial Generation imply negative things as if their existence is a big threat to this nation. They seem to mark a new history of the nation's civilization, whereas, in fact, the image of their existence is nothing but the impact of the increasingly unstoppable flow of technological development hegemony. The biggest mistake of the Millennial Generation is none rather than that they are not able to filter information so that the facts coincide with manipulation; a sign of reality fusion; lies are compounded with the truth. The categories of truth, falsehood, authenticity, issue, reality seem to be invalid. Emotional and heroic reactions quickly occur into the surface, but immediately disappeared somewhere.

In a short time, vernacular literature which for centuries has become a vital element of this nation became extinct by a sarcastic information whirlwind continuing to seize the stage of gadget world, the internet and so on. A world whose existence cannot be separated from the existence of a generation that Strauss-Howe called as "the Millennial Generation", while Don Tapscott called it "Net Generation", and Graham Brown called it the term "Mobile Generation".

Whatever term is attached to them, it is clear that they will ultimately hold the Indonesian literary relay. If their existence is increasingly uprooted from the roots of local wisdom values which are vital elements of this nation, it will be harder for Indonesia to have a smart and virtuous generation. Why? It is because the generation is lacking vernacular literary knowledge fully contained vernacular language, whereas generally, such literary works are contained of the principles of life philosophy and character in applying language and expression.

\subsection{Transformation Steps}

The most obvious step should be taken now is to make a breakthrough step in the form of a transformation step. It is not enough if this nation just continues to struggle in order to make literature which is full of elements of vernacular language being recognized by the world. While on the other hand, its existence is increasingly left behind by its regeneration. To preserve the literary vernacular as an Indonesian intangible cultural heritage, it needs transformation steps so that the existence of literature becomes closer to the Millennial Generation. Being approved or not, they are Indonesia's assets as time goes by it will become the holders of Indonesian literature relay. Is it beautiful if the existence of literature which is laden with elements of vernacular language is recognized by the world, isn't it? Nevertheless, on the other hand, it is not known for its regeneration.

As it is coined by Stian Haklev in Library Philosophy and Practice e-journal with the title Community Libraries in Indonesia: A Survey of Government-Supported and Independent Reading Gardens that actually there is a doubt in whether Indonesian are actually lacking reading interest or simply lacking to affordable 
reading materials. However, this notion had already been answered by international huge book fair being held in Indonesia, Big Bad Wolf, with its main purpose stated in its website to help thousands of Malaysians every year to discover affordable reading (https://www.bigbadwolfbooks.com/). This Big Bad Wolf travels to different countries and offers a vast range of books started from modern classic to children reading. People started to swarm it since it offers $60-80 \%$ of discounts with millions of book titles, therefore it can be seen that people actually have quite an interest in reading proven by visitors' high enthusiasm. The better part is its high demand of this event by the society made it not only held in first and second biggest cities in Indonesia, Jakarta and Surabaya, in the most cramped island in this country, Java, but it is going to be held in Sumatra island too, more precisely in Medan.

The reading interest is there thus it is quite a relief, to say the least that we can still save the next generation to enjoy the reading activity. It is expected that they will start to notice vernacular literature too. From here, in addition, to preserve a series of literary works being recognized by the world as the wealth of this nation, it also needs to make a breakthrough in order to prevent from an extinct of the reality of its regeneration life both in communication and expression. Because when the generation, Millennial Generation is getting familiar to the vernacular literature particularly to local literature, then they will become wiser and more having virtuous in communicating and expressing.

The transformation step needs to be implemented is how to get the literature work closer to the Millennial Generation. Indeed, it cannot work if we force the millennial generation to approach the existence of vernacular literature. However, there is still an opportunity to make vernacular literature more familiar to if the literature comes first to greet them. The most practical way, in this case, is by recognizing the tendency of the Millennial Generation who have a passion for the world of gadgets and the internet.

Therefore, it is important to present vernacular literature in the realm of cyberspace. Of course, through a more Millennial packaging and easier to understand, it is at least as a form of global awareness. How to use technological development to make vernacular literary works become more grounded is not just being in opposing to technological advances. For example, first, it is necessary to provide a special portal for vernacular literature works, in point of view of vernacular terms as a native language.

The portal is certainly not just a form, but also must be equipped with an IT team so that its existence becomes easier to reach. At the very least, when the Millennial Generation search anything related to literary nuances, then this vernacular literature first appeared in the direction of Google's engine organizer. In this case, of course, literature like this are not only able to reach some keywords directly point to the topic, but also as much as possible can reach various kinds of keywords commonly used by the Millennial Generation while searching on the Google machine.

Secondly, applications can also be made on mobile phones whose existence contains literature of having vernacular language. Third, it presents a more dynamic literary vernacular as in an interesting piece of literary language being studied further. It could be in the form of a caption containing quotes as if it is represented their existence. The question is, is this possible? Of course, the answer is very possible because the literary work was born from a long reflection representing people's conditions and feelings from generation to generation because of the existence of multi-interpretation. Only with a little touch, it will be more updated, and then vernacular literary works will again find its stage both in the real world and in cyberspace.

Fourth, vernacular literature, exemplified as the Panji Story, slowly but sure begins to penetrate the real world. It's just a matter of old-fashioned packaging making the literature hasn't been able to steal the attention of the Millennial Generation. In this case, it is not only a matter of quality but relatively inexperienced compared to the work of folklore in Europe, such as the story of Snow White, Cinderella and so forth.

Fifth, raising the awareness of the literary world starts from the family environment. This will be very useful as a foundation for their sons and daughters to be not easily blown away by a series of sarcastic information scattered in cyberspace. One of them is to familiarize the children since early childhood to be fond of reading local literature in the form of folklore and so on. Furthermore, if necessary it needs to make it as a habit for children to attend folk art performances.

If all of those method plans applied personally, it is not impossible to build literary awareness stronger, thus, the narcissistic, selfish, sarcastic generation will be more anticipated by the population growth. On the contrary, a wise and virtuous generation will again emerge to become a prospective Indonesian literary relay holder. The ball is in our courtyard, thus as the scholar and teacher, we need to try some of those ways. 


\section{Conclusions}

From all the discussion above, it can be concluded that to save vernacular literature as an Indonesian Intangible Cultural Heritage. It is not enough just to struggle being recognized by the world. However, it also needs for concrete steps in order to make its existence more acceptable to the next generation. Thus, the existence of vernacular literature is not only preserved as an Intangible Cultural Heritage but also as a national identity.

This is the most essential step to save vernacular literature from extinct whereas in this case, it needs the transformation steps, therefore, the existence of vernacular literature can be more familiar and more acceptable by its regeneration, Millennial Generation. These steps will be more effective if it is accompanied by a debriefing of literary understanding starting from the family environment, a place where the family also has a big contribution in shaping the character of their children. When parents plant the values of local wisdom to the children by familiarizing them to enjoy local literary readings or folklore, then children will grow up into a nation not be easily uprooted from the roots of wisdom, aesthetics, and ethics in language and expression.

\section{References}

1. Astuti, Indriyani. (2018) Pewarisan Tradisi Lisan Secara Alami Sulit Dilakukan. Retrieved from https://mediaindonesia.com/read/detail/202058-pewarisan-tradisi-lisan-secara-alami-sulitdilakukan

2. Big Bad Wolf Books (2018, October 1). Our Story. Retrieved from https://www.bigbadwolfbooks.com/2016/kl/our-story

3. Braginsky, V. (2004). the Heritage of Traditional Malay Literature; a Historical Survey of Genres, Writing and Literary View. Leiden: KITLV

4. Foulcher, K. (1987). Politics and Literature in Independent Indonesia: The View from the Left. Southeast Asian Journal of Social Science, 15(1), pp. 83-103. Retrieved from http://www.jstor.org/stable/24491635

5. Haklev, S. (2010). Community Libraries in Indonesia: A Survey of Government-Supported and Independent Reading Gardens. Library and Philosophy Practice - Electronic Journal Website Digital Commons @ University of Nebraska.12-17. Retrieved from https://digitalcommons.unl.edu/libphilprac/325/

6. Howard, P. (2003). Heritage: Management, Interpretation, Identity, London, Continuum

7. Kemdikbud (n.d) Warisan Budaya Tak Benda. http://gln.kemdikbud.go.id/glnsite/formulirwarisan-budaya-tak-benda/

8. Kushartanti. (2005). Pesona Bahasa; Langkah Awal Memahami Linguistik, Jakarta; Gramedia.

9. McGlynn, J. (2000). Silenced Voices, Muted Expressions: Indonesian Literature Today. Manoa, 12(1), 38-44. Retrieved from http://www.jstor.org/stable/4229817

10. Purbatjaraka, R.M.Ng. (1968). Tjerita Panji dalam Perbandingan. Jakarta; Gunung agung

11. Suwondo, T (2008) Dinamika Sastra Indonesia di Tengah Kebinekaan Sastra Daerah. Jakarta; Horison.

12. Thesaurus Heritage. (n.d). Retrieved from https://www.merriamwebster.com/thesaurus/heritage 